\title{
Björn Hoops*
}

\section{Legal Certainty is Yesterday's Justification for Acquisitions of Land by Prescription. What is Today's?}

https://doi.org/10.1515/eplj-2018-0008

\begin{abstract}
Legal certainty is the traditional justification of land acquisitions by prescription in the Netherlands and elsewhere. However, as land information systems become more comprehensive and reliable, this justification increasingly loses its foundation. Only where a transfer is invalid despite a registered transfer deed, is this justification still fully persuasive. This article examines alternative justifications of land acquisitions by prescription and assesses whether the requirements for acquisitions by prescription under Dutch law already reflect these justifications. The owner's omission to monitor the use of the land is arguably a persuasive justification for the loss of ownership by prescription and is fully reflected by the requirement of 'possession'. However, it fails to explain why a possessor who knowingly occupies somebody else's land should become owner. This article proceeds to evaluate the labour theory, the personhood theory, the theory of human flourishing, and utilitarian approaches. These theories persuasively explain why a bad faith possessor should become owner, but are not reflected by Dutch law. As a last step, this article considers the reduction of wealth inequality as a justification of land acquisitions by prescription and concludes that tempting though this justification may be, prescription is not an adequate means to combat inequality.
\end{abstract}

\section{Introduction}

In the world of yesterday with no, deficient, or incomplete land registers, some land owners struggled to prove their title to the land in their dispute with a (at least initially) wrongful user. In yesterday's world, physical control of the land was an essential indicator of who had a right to use the land. If the user acted as if owner for a long period of time, the physical appearance prompts people to think

\footnotetext{
*Corresponding author: Dr. Björn Hoops, LL.M., Department of Private Law and Notarial Law, Faculty of Law, University of Groningen, E-Mail: b.hoops@rug.nl
} 
that the user is also owner. As evidence slowly deteriorates, the owner finds it increasingly difficult to prove his/her title. At some point, many jurisdictions then reallocate ownership to the user to avoid wasteful legal disputes and ensure that the land remains marketable. ${ }^{1}$ In civil law jurisdictions, this acquisition by the user is called an acquisition by prescription. In common law jurisdictions, the functional equivalent is adverse possession. The described justification for this mode of acquisition is commonly referred to as legal certainty.

In the world of today, however, there is typically a well-functioning and fairly complete land register in place in each jurisdiction in the Global North. The more reliable a country's land register is, the less difficulty the owner has in proving his rights to the land and the less convincing a legal certainty-related justification for acquisitions by prescription becomes. This is also true for the Netherlands, which is the focus of this contribution to ensure a thorough analysis of one national system of land registration and its links to acquisitions by prescription. This contribution first investigates whether and, if so, in what cases legal certainty still justifies acquisitions by prescription in the Netherlands. In cases where legal certainty can no longer justify acquisitions by prescription, the question arises of whether there is still any justification for acquisitions by prescription in the Netherlands. If not, the law on acquisitions by prescription should no longer be applicable to such cases. This contribution examines whether the punish the neglectful owner'-rationale, Locke's labour theory, personality theories, economic efficiency, and/or the promotion of economic equality may justify acquisitions by prescription in the Netherlands. If that is the case, this contribution proceeds to inquire whether Dutch law as it is reflects the persuasive justifications. For, if the requirements for acquisitions by prescription are not consistent with this justification, Dutch law would have to be adjusted before a goal can be said to justify acquisitions by prescription. ${ }^{2}$ Note that this contribution assumes that the consequence of an acquisition by prescription is a reallocation of ownership. A discussion of whether intermediate solutions between acquisition of ownership and no ownership, such as the creation of limited property rights or the payment of compensation to the former owner along with an acquisition of ownership, are more desirable and could be justified more easily, falls outside the scope of this contribution. Before turning to the justification of acquisitions by prescription

1 See, for instance, for the debate in England: M. Dockray, 'Why do we need adverse possession?' [1985] Conveyancer 272-284; JA Pye (Oxford) Ltd and Another v Graham and Another [2000] Ch 676, 709-710; Law Commission, Land Registration for the Twenty-First Century: A Conveyancing Revolution, No. 271 (The Stationery Office 2001).

2 E.J. Marais, Acquisitive Prescription in View of the Property Clause (unpublished LLD thesis, Stellenbosch 2011), 152. 
under Dutch law, this contribution first gives a brief introduction to the law on acquisitions by prescription in the Netherlands.

\section{Acquisitive and Extinctive Prescription under Dutch Law}

Prescription is a mode of acquiring land (and other things or assets) under the Dutch Civil Code (Burgerlijk wetboek; BW). ${ }^{3}$ The Dutch Civil Code recognises two types of acquisitions by prescription. The first type of an acquisition by prescription is acquisitive prescription under Art. 3:99 BW. The second type is an acquisition by extinctive prescription under Art. 3:105 BW.

\subsection{Acquisitions by Acquisitive Prescription}

Art. 3:99(1) BW poses three requirements for an acquisition by acquisitive prescription:

(I) Possession;

(II) uninterrupted for 10 years; and

(III) in good faith.

\section{(I) Possession (Bezit)}

A user of land who invokes acquisitive prescription must be possessor of the land. Possession is defined as holding a thing or asset for oneself. ${ }^{4}$ This means that a possessor not only exercises (physical) control over an object, but also exercises this control as if $\mathrm{s} /$ he were owner. ${ }^{5}$ Whether or not a user exercises physical control for themselves is determined according to common opinion (verkeersopvatting) and the facts as they appear. ${ }^{6}$ Higher standards apply to the physical

3 Art. 3:80(1) and (3) BW.

4 Art. 3:107(1) BW.

5 E.B. Rank-Berenschot, Bezit (Kluwer 2012) 3. As Jansen has pointed out, this does not necessarily mean that the possessor pretends to be owner. His actions merely appear to be the actions of an owner. For instance, a thief knows that $\mathrm{s} /$ he is not the owner and does not necessarily pretend to be owner. J.E. Jansen, Bezit te kwader trouw, verkrijgende en bevrijdende verjaring (Boom 2011) 270 et seq. If $\mathrm{s} / \mathrm{h}$ e exercises physical control for somebody else, $\mathrm{s} / \mathrm{he}$ is a detentor and cannot acquire by prescription. See Art. 3:110 and 111 BW; and cf. J.A. Lovett, 'Precarious Possession' [2017] Louisiana Law Review 617-700.

6 Art. 3:108 BW. 
control of a person who takes possession of a thing or an asset that belongs to somebody else. ${ }^{7}$ The physical control must be so extensive as to put an end to the possession of the owner. ${ }^{8}$ More specifically, the appearance of ownership must be visible to the owner and so unambiguous that the owner could only infer from the user's actions that the user was acting as if owner. ${ }^{9}$

These abstract guidelines only give a rough indication of what constitutes possession in a specific case. In a study on a random sample of 60 judgments on acquisitive prescription of lower courts in the Netherlands, I found that the owner of the land, the type of land, and its function affect the interpretation of "possession". ${ }^{10}$ A user can take possession of publicly owned land by using it exclusively and putting up a fence or a hedge around it. ${ }^{11}$ If the land used to be part of a public road, the public sidewalk or a publicly owned verge between a private residence and a road, some courts require the user to do even more than put up a fence or hedge around the land. ${ }^{12}$ More lenient requirements apply to publicly owned agricultural land..$^{13} \mathrm{~A}$ user can take possession of privately owned land by exclusively using the land and indicating the new boundary by, for instance, placing a fence, boundary stones, or flower tubs. ${ }^{14}$

7 Art. 3:113(2) BW.

8 Hoge Raad (HR), 18 September 2015, ECLI:NL:HR:2015:2743, para 3.4.2; S.E. Bartels \& A.I.M. van Mierlo, Mr. C. Assers Handleiding tot de beoefening van het Nederlands Burgerlijk recht, 3-IV, Vermogensrecht algemeen, Algemeen goederenrecht (16th edn, Kluwer 2013), No. 140; RankBerenschot (note 5), 49; and Jansen (note 5), 272.

9 Hoge Raad (HR), Judgment of 24 February 2017, ECLI:NL:HR:2017:309, para. 3.3.2; and C.J. van Zeben, J.W. du Pon \& M.M. Olthof, Parlementaire geschiedenis van het nieuwe burgerlijk wetboek, Boek 3, Vermogensrecht in het algemeen (Kluwer 1981) 408.

10 B. Hoops, 'Het ene hek is het andere niet: Hoe de omgeving van grond en zijn eigenaar het bezitsvereiste in verjaringszaken inkleuren' [2017] WPNR 1045-1053; and B. Hoops, 'Landjepik in Nederland: Een verkennend empirisch onderzoek naar het gebruik zonder recht van gemeentegrond (Illegal Land Use in the Netherlands: An explorative empirical study on the use of municipal land without any right)', 2017, working paper, available at https://papers.ssrn.com/so 13/papers.cfm?abstract_id=3080849.

11 Compare Gerechtshof Den Bosch ,11 October 2016, ECLI:NL:GHSHE:2016:4559, para 3.10 to Gerechtshof Den Bosch, 27 September 2016, ECLI:NL:GHSHE:2016:4295, para 3.5.7.

12 Gerechtshof Den Bosch, 1 September 2015, ECLI:NL:GHSHE:2015:3422, para 3.3.2.

13 Gerechtshof Den Haag, 28 June 2011, ECLI:NL:GHSGR:2011:BQ9908, para 4.3.2.1 et seq.

14 Gerechtshof Den Bosch, 17 November 2009, ECLI:NL:GHSHE:2009:BK7631, para 4.7 et seq. 


\section{(II) Uninterrupted for a Period of 10 Years}

A prescription period of 10 years applies to immovable property. During this period, possession must be uninterrupted. If the user involuntarily loses the possession, the possession will be deemed uninterrupted if the user regains or brings an action for regaining the possession within a year after the loss. ${ }^{15}$

\section{(III) Good Faith (Goede trouw)}

A user can only rely upon acquisitive prescription if s/he acts in good faith. Acting in good faith means that the user believes and does not have to doubt that $\mathrm{s} / \mathrm{he}$ is the owner. It is sufficient for the user to hold this belief on reasonable grounds at one point during the prescription period. ${ }^{16}$ Once the user is in good faith, $\mathrm{s} /$ he is deemed to continue to act in good faith. ${ }^{17}$ It would thus be irrelevant if the possessor later took (or should have taken) note of the fact that the thing or asset is actually somebody else's.

With respect to immovable property, the Dutch system of land registration has got implications for the interpretation of the requirement of good faith. The public records (Openbare register) are a repository of notarial deeds and other legal documents concerning the legal status of immovable property and other things and assets that can only be transferred through registration in the public records. ${ }^{18}$ The Dutch Civil Code stipulates that the user will never be in good faith if $\mathrm{s} /$ he claims to be ignorant of information contained in the public records. ${ }^{19}$ In other words, there is an obligation to check the public records. The notarial deeds concerning a parcel of land include its size, a very abstract description of the location and type of land, ${ }^{20}$ but usually no map or another detailed description of the parcel's boundaries. ${ }^{21}$ If the user possesses somebody else's land that is not adjacent to his/her own or that is a substantial part (or more) of an adjacent parcel, s/he will generally not act in good faith. The user would only be in good

15 Art. 3:103 BW.

16 P.C. van Es, Verkrijging door verjaring (Ars Aequi Libri 2011) 39; and Van Zeben et al (note 9), 410 and 444.

17 Art. 3:118(1) and (2) BW.

18 A. A. van Velten, Privaatrechtelijke aspecten van onroerend goed ( $4^{\text {th }}$ edn, Kluwer 2012) 350 et seq.

19 Art. 3:23 BW.

20 Art. 20(1) of the Land Cadastre Act (Kadasterwet).

21 This is only obligatory if a parcel is split: M.H.G. Giesbers, in W.D. Kolkman \& L.C.A. Verstappen (eds), Handboek Registergoederenrecht 15/16, Deel 1 (Walburg Pers 2014) 160. 
faith if a notarial transfer deed was registered in favour of the user on the basis of a void (or avoided) contract and the user believed on reasonable grounds that the transfer was valid. ${ }^{22}$

If the user only possesses a small part of somebody else's parcel that is adjacent to his/her own, s/he might act in good faith. If the user moved the boundary of his/her parcel and expanded it on his/her neighbour's parcel, she will not act in good faith. ${ }^{23}$ If the user purchased the illegally used land from the previous owner of his/her parcel and that land physically formed a unit with the parcel, she will generally act in good faith. ${ }^{24}$ The public records usually do not contain a detailed map from which to infer the boundaries of the involved parcels. ${ }^{25}$ The land register (Basisregistratie Kadaster) provides maps on the basis of the information contained in the public records and surveying records. ${ }^{26}$ There is, however, no obligation for the user to check the land register. Only if there is an indication in the physical environment of the land that the user uses somebody else's land, will s/he have to consult the land register or otherwise not act in good faith. $^{27}$

\subsection{Acquisitions by Extinctive Prescription}

Art. 3:105(1) BW links the extinctive prescription of the owner's rei vindicatio to the loss of ownership to the possessor of the thing or asset at the moment that the owner's action prescribes. It does not play a role whether or not the possessor acts in good faith. An acquisition of land by extinctive prescription is thus subject to two requirements:

(I) possession; and

(II) the owner's rei vindication has prescribed.

22 Van Zeben et al (note 9), 409 et seq; and Van Velten (note 18), 382 et seq.

23 Hoge Raad (HR), 20 February 1987, ECLI:NL:HR:1987:AG5543; Hoge Raad (HR), 10 December 1976, ECLI:NL:HR:1976:AC1711; and Bartels \& Van Mierlo (note 8), Nos. 546 et seq.

24 Hoge Raad (HR), 20 June 1997, ECLI:NL:HR:1997:ZC2399; and Van Es (note 16), 37 et seq.

25 Cf. Giesbers (note 21), 160.

26 W. Louwman \& W.F.L. van der Bruggen, in Kolkman \& Verstappen (note 21), section 7.3.

27 B. Hoops, 'Te goeder trouw, te kwader trouw of geen van beide? Wegwijs in de nieuwe verjaringsverkrijgingsjungle’ [2017] WPNR 983-990. 


\section{(I) Possession}

'Possession' should have the same substantive content throughout the whole civil code, regardless of whether 'possession' is required for acquisitive prescription or extinctive prescription. However, some judgments of lower courts suggest that the courts subject the physical control exerted by bad faith users to stricter requirements. ${ }^{28}$

\section{(II) Rei vindicatio Has Prescribed}

The general prescription period is 20 years. ${ }^{29}$ This means that at the moment 20 years have gone by since the owner lost possession of the land, the possessor at that very moment will become owner..$^{30} \mathrm{~A}$ recent judgment of the Dutch Supreme Court (Hoge Raad; HR) has added a nuance to this aspect. A user may have illegally used the land without his physical control being extensive enough to constitute possession. According to that judgment, the period of this illegal land use must be added to the period in which owner lacked possession when it is calculated whether the 20-year-period has lapsed. ${ }^{31}$ This means that for example, a user who illegally used land for 19 years without being possessor and then became possessor, would become owner after one year of being possessor.

On 24 February 2017 the Dutch Supreme Court unexpectedly improved the legal position of persons who lost their ownership on the basis of Art. 3:105 BW. If the user knew that $\mathrm{s} /$ he was taking possession of somebody else's land, $\mathrm{s} / \mathrm{he}$ would commit an unlawful act as against the owner. ${ }^{32}$ The former owner would have a claim to damages against the user. Judges have the discretion to award damages in kind, ${ }^{33}$ which means that the courts may order a transfer of the land acquired by prescription back to the former owner. The Supreme Court ruled that this claim would only prescribe five years after the former owner got aware of the loss of ownership and the acquirer by prescription, but not more than 20 years

28 Compare Gerechtshof Amsterdam, 31 January 2017, ECLI:NL:GHAMS:2017:264, para 3.8 to Gerechtshof Amsterdam, 23 June 2015, ECLI:NL:GHAMS:2015:2548, para 3.10 and Gerechtshof Amsterdam 25 August 2015, ECLI:NL:GHAMS:2015:3495, para 3.13.

29 Art. 3:306 BW.

30 Hoge Raad (HR), 10 August 2012, ECLI:NL:HR:2012:BW5324.

31 Hoge Raad (HR), 4 September 2015, ECLI:NL:HR:2015:2463. Cf J.E. Jansen, 'Drie uitspraken over erfpacht, inbezitneming en art. 3:105 BW' [2015] Maandblad voor Vermogensrecht 255, 260 et seq.

32 Hoge Raad (HR), 24 February 2017, ECLI:NL:HR:2017:309, para 3.7.3.

33 Art. 6:103 BW. 
after the acquisition by prescription. ${ }^{34}$ As this rule only applies to bad faith acquirers ("land thieves"), this judgment is an expression of the value judgement that theft should not be rewarded and the fear that acquisitions by prescription could give rise to an incentive to occupy land..$^{35}$

\section{The Fading Importance of the Traditional Justification of Acquisitions by Prescription}

In the Netherlands, the traditional goal of acquisitions of land by prescription is to promote legal certainty. This goal assumes different shapes, depending upon the factual and legal situation at hand. When the user acts in good faith and a notarial transfer deed has been registered, but the transfer turns out to be invalid, the public records and the land register indicate the wrong owner. To the extent that the user (or his/her successor) does not meet the requirements for third-party protection, ${ }^{36}$ acquisitive prescription ensures that the registers reflect the actual legal situation, protects the justified expectations of the user and his/her successors in title, and safeguards the marketability of the land. ${ }^{37}$ These effects make legal certainty a solid justification of acquisitive prescription in such cases.

If, however, no notarial transfer deed has been registered, the implications of acquisitions by prescription for legal certainty are less straightforward. The public records and the land register still indicate the right owner, which means that it is unnecessary for an acquisition by prescription to correct the publicly available information. On the contrary, acquisitions by prescription render the public records and the land register less reliable because an acquirer by prescription does not need to register the acquisition, not even for third-party effect. ${ }^{38}$ This means that persons who purchase the land from the original owner and have a

34 Art. 3:310 BW. Hoge Raad (HR), 24 February 2017, ECLI:NL:HR:2017:309, para 3.7.4.

35 B. Hoops \& L.C.A. Verstappen, 'Van 20 naar 40 jaar: De Hoge Raad helpt eigenaars in de strijd tegen landjepik', [2017] WPNR 255-257. Cf contributions on this issue before this judgment of the Supreme Court: F. Brandsma, 'Enige mededelingen over de verkrijgende verjaring van onroerend goed en de overschrijving', [1989] Groninger Opmerkingen en Mededelingen 1, 42; and M.A.B. Chao-Duivis, 'Dief wordt eigenaar...en blijft dat (helaas)!', [1996] WPNR 732-734.

36 Cf. Art. 3:88 BW.

37 W.H.M. Reehuis \& A.H.T. Heisterkamp, Pitlo, Deel 3, Goederenrecht (13th edn, Kluwer 2012), No. 330; Van Velten (note 18), 379 et seq and 382 et seq; and Van Es (note 16), 43 et seq.

38 Art. 3:24(2) lit. e BW. See Jansen (note 5), No. 142; Van Velten (note 18), 379 et seq; and W.D. Kolkman, L.C.A. Verstappen, R.J.L. Timmer \& F.J. Vonck, Verbetering betrouwbaarheid Basisregistratie Kadaster (Boom 2012). 
notarial transfer deed registered have to respect the acquisition by prescription and cannot invoke the publicly available information as against the acquirer by prescription. It thus appears that prescription undermines rather than promotes legal certainty in such cases.

If it is to be persuasive, any justification of acquisitions by prescription on grounds of legal certainty would thus have to show that an acquisition by prescription in a specific case does not render the public records and the land register less reliable or that the acquisition serves a more important, legal certainty-related interest. In Dutch law, the traditional justification of acquisitions by prescription is that the legal status of a thing should be adjusted to the physical appearance of its legal status after a certain period of time. ${ }^{39}$ In other words, as the user appears to be owner through the possession of the land, s/he should become owner after the prescription period has lapsed.

Although this justification is used to justify both types of acquisitions by prescription, it is particularly relevant to acquisitions by extinctive prescription. Before the introduction of the new Dutch civil code of 1992, the user did not become owner after the owner's rei vindicatio had prescribed. This entailed that the owner could no longer enforce the ownership, while the user could not transfer the land or use it as collateral. ${ }^{40}$ Since the introduction of the new Civil Code, Art. 3:105 BW has avoided this legal uncertainty and ensures the marketability of the land within a regime that foresees the extinctive prescription of the rei vindicatio.

The essential question is of what the benefits are of the adjustment of the land's legal status to its physical appearance compared to a regime that provides for neither acquisitive prescription nor the extinctive prescription of the rei vindicatio. It is said that third parties should eventually be able to rely upon the appearance of the land's legal status, which may facilitate market transactions..$^{41}$ Another potential benefit would be that the law sets a deadline for the owner to bring an action against the user. The user knows at what point in time s/he will be

39 Van Zeben et al (note 9), 416; Bartels \& Van Mierlo (note 8), No. 536; and A.C. van Schaick, Monografieën Nieuw BW, A14, Rechtsgevolgen en functies van bezit en houderschap (2nd edn, Kluwer 2014) No. 94. Cf. J. Van de Voorde, De verkrijgende verjaring. De nalatenschap van Rome heroverwogen (University of Antwerp 2017), Nos. 139 et seq.

40 Jansen (note 5), 8 and 255. Cf. A. Bergmann, Der Verfall des Eigentums (Mohr Siebeck 2015), 18 et seq.

41 Bartels \& Van Mierlo (note 8), No. 536. Cf. Marais (note 2), 154; J.G. Sprankling, 'Environmental Critique of Adverse Possession' [1994] Cornell Law Review 816, 819 et seq; R. A. Epstein, 'Past and Future: The Temporal Dimension in the Law of Property' [1986] Washington University Law Quarterly 667, 676 et seq; and M.J. Goodman, 'Adverse Possession of Land - Morality and Motive' [1970] The Modern Law Review 281, 282 et seq. 
safe from the owner's actions, and the owner knows by when s/he needs to act. ${ }^{42}$ This deadline prevents fruitless litigation because as time progresses, people may find it increasingly difficult to prove all necessary facts to establish their right or to successfully raise a defence against the other party's action. ${ }^{43}$ With respect to good faith acquirers (under either Art. 3:99 BW or Art. 3:105 BW), prescription can be said to protect their legitimate expectations and facilitates transfers to thirdparty purchasers.

If the user possesses a parcel of land that is not adjacent to the user's parcel, it is very difficult to imagine how an acquisition by prescription that does not heal a flawed transfer is supposed to serve legal certainty. The public records and the land register reliably indicate the owner of the parcel so that there is generally no uncertainty as to the land's legal status for the owner, the user, or a third party. ${ }^{44}$ The user's interest in being able to rely upon the owner's inaction and being protected from a late action for eviction cannot - in my view - outweigh the public interest in the reliability of the public records and the land register, in particular because the register is so reliable that the user would be able to prove a right to the land if s/he had any. Also, the public's interest in the user being protected is not as strong as is often believed. Acquisitions by prescription do not necessarily prevent litigation because the (former) owner may still bring an action and try to prove that the user does not meet the requirements for an acquisition. ${ }^{45}$

The conclusion would only be different where the whereabouts of the owner are unknown or where the owner has died and his/her heirs are unknown. ${ }^{46}$ Such

42 Jansen (note 5), 255; J. L. Smeehuijzen, De bevrijdende verjaring (Free University of Amsterdam 2008) 19-71; and M.W.E. Koopmann, Monografieën B14, Bevrijdende verjaring (Kluwer 2010) 21. Refer for the debate on this justification in other jurisdictions to, for instance, T.W. Merrill, 'Property Rules, Liability Rules, and Adverse Possession', [1984-1985] Nw. U. L. Rev. 1122, 1129 et seq; Marais (note 2), 164 et seq; Sprankling (note 41), 819 et seq; and Epstein (note 41), 677 et seq.

43 Reehuis \& Heisterkamp (note 37), No. 331; Bartels \& Van Mierlo (note 8), No. 536; and Koopmann (note 42), 21. Refer for the debate on this aspect in other jurisdictions to, for instance, Epstein (note 41), 677 et seq; Merrill (note 42), 1128; V. Sagaert, 'De verkrijgende verjaring van onroerende goederen herbezocht. Een aanzet tot het debat over het verjaringsrecht' [2007] Rechtskundig Weekblad 1582; and J.E. Stake, 'The Uneasy Case for Adverse Possession' [2001] The Georgetown Law Journal 2419, 2439 and 2451 et seq.

44 Hoops (note 27).

45 W. Saxe, 'When “Comprehensive” Prescriptive Easements Overlap Adverse Possession: Shifting Theories of "Use” and "Possession”' [2006] Boston College Environmental Affairs Law Review 175, 201; and N. Elfant, 'Compensation for the Involuntary Transfer of Property Between Private Parties: Application of a Liability Rule to the Law of Adverse Possession' [1984-1985] Northwestern University Law Review 758, 777.

46 Where there are no heirs, the state will become the owner under Dutch law. See Art. 4:189 BW. Where the heirs are unknown, the state can decide on whether or not to sell the land, but will 
situations would threaten the productive use and marketability of the land. This finding is confirmed by $\S 927$ of the German Civil Code (Bürgerliches Gesetzbuch; BGB). The German Civil Code precludes the extinctive prescription of registered rights in land and acquisitions by prescription that are not based upon a flawed entry in the land register. ${ }^{47}$ However, a person who has been possessing land as if owner for 30 years may apply to the court for an elimination of the registered owner's rights in the land if the registered owner is dead or has been lost without a trace. If the elimination is granted, the possessor will obtain a right to acquire the land through registration in the land register. Interestingly, like the goal of Art. 3:99 and $105 \mathrm{BW}$, the main goal of this procedure is to prevent the actual control of the land from permanently deviating from the land's legal status as enshrined in the land register. ${ }^{48}$

The assessment grows more complicated when it comes to boundary disputes, which are by far the most common application of acquisitions by prescription in the Netherlands. ${ }^{49}$ If a notarial transfer deed clearly describes the boundary (or even contains a map), this boundary will apply (regardless of what the parties may have agreed upon before or after the transfer) and there will be no uncertainty. ${ }^{50}$ If the notarial transfer deed only describes the boundary in abstract or unclear terms, the boundary determined by the parties and recorded by the Netherlands' Cadastre, Land Registry and Mapping Agency (Kadaster) in the land register will grow in importance. If the boundary is ascertainable on the basis of land register, this boundary will apply unless a party contesting this boundary can prove that another boundary was agreed upon by the parties to the most recent transfer. ${ }^{51}$ As the land register is a digitalised and generally reliable source of information, this would suggest that there is no uncertainty that would have to be cured by an acquisition by prescription.

only become owner 20 years after the deceased owner's death. See Art. 4:226 BW. Moreover, inheritances often remain unregistered and threatens the reliability of the land register; see Kolkman et al (note 38). Cf J. Wylie, 'Adverse possession - still an ailing concept' [2017] Irish Jurist 1, 10; and M.J. Radin, 'Time, Possession, and Alienation' [1986] Washington University Law Quarterly 739, 746.

47 Cf. $\S \S 900$ and 902 BGB.

48 J. Heisel, Grundbuchbereinigung durch Aufgebot (Carl Heymanns Verlag 2009) 4 and 21.

49 Hoops (note 10).

50 P.G.H.T. Konings, De openbare registers ten hypotheekkantore (Kluwer 1990) 112 and 116; Bartels \& Van Mierlo (note 8), No. 499; Hoge Raad (HR), 8 December 2000, ECLI:NL:HR:2000: AA8901; Hoge Raad (HR), 2 December 1988, ECLI:NL:HR:1988:AB8205; and Hoge Raad (HR), 6 June 1986, ECLI:NL:HR:1986:AB9435.

51 Konings (note 49), 114 and 116 et seq; and Bartels \& Van Mierlo (note 8), Nos. 514 and 526. 
Even the expectations of good faith acquirers, who are not necessarily obliged to consult the land register under current law, do not seem strong enough to justify the acquisition. However, the information recorded in the land register is not necessarily of such quality that the boundary can be ascertained..$^{52}$ In such cases, there is a need to adjust the land's legal status to its appearance to avoid legal uncertainty. However, even then, the public interest in legal certainty does not necessarily outweigh the public interest in not rewarding land theft and preventing an incentive to occupy land, ${ }^{53}$ which is at risk under Art. 3:105 BW.

Concluding, as the reliability and completeness of the land register improves, the traditional justification becomes increasingly less persuasive. ${ }^{54}$ There is thus a widening theoretical vacuum, which needs to be filled with alternative justifications for acquisitions by prescription.

\section{The Owner's Negligence as a Justification of Acquisitions by Prescription}

The user's physical control of the land without the owner's permission over a long period of time implies that the owner does not use the land and either does not monitor its use or does not care about how it is used. If one assumes that there is an obligation for owners to look after their land, the owner's breach of this obligation can serve as a justification of the user's acquisition by prescription.

This argument can be traced to several jurisdictions and may surface in two different shapes. The more common type is that the acquisition by prescription punishes the owner for not monitoring and controlling the use of the land in order to avoid that owners "sleep on their rights". ${ }^{55}$ The second and less common type

52 Bartels \& Van Mierlo (note 8), Nos. 514 and 526.

53 Cf. Van de Voorde (note 39), Nos. 1906 et seq.

54 See for similar conclusions in contributions from other jurisdictions: Wylie (note 46), 9 and 12; Sagaert (note 43), 1594; C.N. Brown, 'Rethinking Adverse Possession: An Essay on Ownership and Possession' [2010] Syracuse Law Review, 583, 587; T.J. Miceli \& C.F. Sirmans, 'An Economic Theory of Adverse Possession' [1995] International Review of Law and Economics 161-173; Marais (note 2), 162; and Sprankling (note 41), 822 et seq.

55 H. Conway \& J. Stannard, 'The Emotional Paradoxes of Adverse Possession' [2013] Northern Ireland Legal Quarterly 75, 79 et seq; L. Katz, 'The Moral Paradox of Adverse Possession: Sovereignty and Revolution in Property Law' [2010] McGill Law Journal 47, 68; Marais (note 2), 151, 158 et seq and 166; L.A. Fennell, 'Efficient Trespass: The Case for 'Bad Faith' Adverse Possession' [2006] Northwestern University Law Review 1037, 1057 and 1059 et seq; and Stake (note 43), 2434 et seq. 
is that the acquisition by prescription punishes the owner for not using the land and encourages an effective use of land. ${ }^{56}$

\subsection{The Failure to Monitor and Control the Use}

Jansen introduced the first type as a form of forfeiture of ownership to the scholarly debate in the Netherlands, ${ }^{57}$ and the European Court of Human Rights used it to substantiate its conclusion that the Grahams' acquisition by adverse possession in the Pye case served a public interest and reflected an equitable balance between the involved interests. ${ }^{58}$ However, neither Jansen nor the European Court pinpoints the public interest in punishing owners for not monitoring and controlling the use of their land. This is problematic because at least at first glance, the additional value of this justification compared to the legal certaintyrelated justification seems rather limited. It is said that the user's possession reduces legal certainty and an acquisition by prescription is needed to restore it. However, as land cannot be moved and the use of land is generally easy to monitor, the user's possession pre-supposes the owner's choice to be inactive. ${ }^{59}$ With respect to land, the legal certainty-related justification thus already incorporates the owner's failure to act. To the extent that the owner's inactivity does not jeopardise legal certainty, as has been set out in the previous section, it therefore seems that the owner's failure to monitor and control the use of the land shares the fate of legal certainty and does not constitute an adequate justification of acquisitions by prescription.

That said, there may be a public interest in owners monitoring and controlling the use of their property that is distinct from the public interest in legal

56 Stake (note 43), 2435; Sprankling (note 41), 820; and Merrill (note 42), 1130.

57 Jansen (note 5), 291 et seq. Cf. C.J.H. Brunner, 'Dief wordt eigenaar' in E.H. Hondius, W.G. Huijgen, Jac. Hijma et al (eds), Quod Licet. Kleijn-Bundel (Kluwer 1992) 45-53; and N. Cobb \& L. Fox, 'Living outside the system? The (im)morality of urban squatting after the Land Registration Act 2002' [2007] Legal Studies 236, 250, who see the failure to monitor and control the use of the land as quasi-abandonment.

58 European of Human Rights (ECtHR), Grand Chamber, 30 August 2007, J.A. Pye (Oxford) Ltd and J.A. Pye (Oxford) Land Ltd v. The United Kingdom, App. No. 44302/02, paras 67 et seq.

59 The visibility of the user's physical control is, moreover, a requirement for possession under Dutch law; see Hoge Raad (HR), Judgment of 24 February 2017, ECLI:NL:HR:2017:309, para. 3.3.2. This makes that although an advertent omission to monitor the use of the land is not an express requirement of an acquisition by prescription, it is an implicit requirement and may serve as an implicit justification. Cf. E.M. Peñalver \& S.K. Katyal, 'Property Outlaws' [2007] U. Pa. L. Rev. 1095, 1171. Differing: Marais (note 2), 152. 
certainty. As land is a valuable and limited resource, wasteful conflicts over land use should be avoided. Continuous illegal land use encourages users to develop an economic, social or emotional bond with the land and make investments, which may be irrecoverable if the owner claims the land back. ${ }^{60}$ Such a reliance interest is almost certain to lead to heavy conflicts where the owner seeks to evict the user. By threatening to make the user owner after a certain period of time, the law encourages the owner to monitor the use of the land and, if so desired, lay down the rights and obligations of non-owners in an agreement. ${ }^{61}$ Another public interest, it is said, is that regular monitoring may reduce transaction costs because the owners are more easily identifiable. ${ }^{62}$ However, this reduction would only occur where there is no reliable land register or where the identification of the owner is otherwise impeded.

The public interest in averting unjustified reliance interests and land conflicts also withstand the reasons against the owner's obligation to monitor the use of land. Some scholars argue that ownership includes the right to neglect one's property, which makes that acquisitions by prescription cannot be based upon an obligation to monitor. ${ }^{63}$ However, as ownership is subject to limitations in the public interest, and it is primarily for the legislator to define these limitations within constitutional and international boundaries, ${ }^{64}$ the public interest in averting land conflicts may justify acquisitions by prescription.

Scholars from the United States and elsewhere point to the historical roots of the justification that owners who sleep on their rights need to be punished, and argue that these roots can no longer justify acquisitions by prescription. In the $19^{\text {th }}$ century, settlers in the United States did not have legal access to vast plots of land west of New England because the owners from New England did not care about the land and lived far away. Acquisitions by prescription were thus a welcome instrument to ensure access to land for the landless and discourage land speculation. Those scholars argue that the problem of landlessness, possibly caused by land speculation, is no longer a major issue and that society no longer

60 Cf. Merrill (note 42), 1131; J.W. Singer, 'The Reliance Interest in Property' [1988] Stanford Law Review 611, 664; and C.M. Rose, 'Possession as the Origin of Property' [1985] The University of Chicago Law Review 73, 81.

61 See for an argument with a similar conclusion: Katz (note 55), 75 et seq.

62 Marais (note 2), 168; Sagaert (note 43), 1594 et seq; and Stake (note 43), 2442 et seq.

63 Conway \& Stannard (note 55), 79 et seq; Merrill (note 42), 1130; C.G. Van der Merwe \& M.J. de Waal, The Law of Things and Servitudes (LexisNexis 1993) No. 105; and Stake (note 43), 2434 et seq. Cf. Cobb \& Fox (note 57), 243 et seq.

64 B. Hoops, 'Taking Possession of Vacant Buildings to House Refugees in Germany: Is the Constitutional Property Clause an Insurmountable Hurdle?' [2016] European Property Law Journal 26-50. 
views it as desirable to punish owners who sleep on their rights. ${ }^{65}$ It is doubtful whether this is really an accurate observation. Landlessness, whether or not caused by land speculation, is still a major problem in the Global South. ${ }^{66}$ In the Global North, a shortage of housing in densely developed and populated urban areas, whether or not in the aftermath of a financial crisis and many foreclosure proceedings, also poses considerable challenges today. Moreover, even if the original argument in favour of punishing the owner were (entirely or partially) outdated, other public interests, such as the one presented here, could still justify punishing the owner.

Another concern is that acquisitions by prescription would drive up monitoring costs. This argument is not persuasive because the costs of monitoring the use of land once every few years is not excessive, ${ }^{67}$ particularly when compared to the privilege of having land at one's disposal. Another argument against this justification of acquisitions by prescription is that an acquisition by prescription is unnecessary to encourage monitoring. Extinctive prescription would be sufficient. ${ }^{68}$ This argument, however, is not persuasive because it would bring back the situation under the old Dutch Civil Code and threaten the marketability of land.

An objection of considerable weight to this justification is that the owner's negligence and the public interest in averting wasteful land conflicts do not outweigh the public interest in not rewarding land theft and preventing an incentive to occupy land. ${ }^{69}$ The owner's negligence itself may justify the loss of ownership by the owner, but cannot justify the acquisition of ownership by a bad faith user. Moreover, allowing bad faith users to acquire land by prescription may create an incentive to occupy land and, thereby, lays the foundation for the wasteful conflicts over land that acquisitions by prescription are supposed to avoid. The public interest in averting wasteful land conflicts thus rather militates against bad faith acquisitions by prescription. For this reason, it is submitted that the justification discussed in this sub-section is insufficient to justify bad faith acquisitions by prescription. It should be examined whether there are normative

65 Stake (note 43), 2435; Sprankling (note 41), 816 et seq; and Sagaert (note 43), 1582.

66 Marais (note 2), 153. Cf. Stake (note 43), 2444 et seq.

67 Merrill (note 42), 1130; and Peñalver \& Katyal (note 59), 1111 et seq.

68 Sagaert (note 43), 1594.

69 V. Sagaert, 'Prescription in French and Belgian Property Law after the Pye Judgment' [2007] European Review of Private Law 265, 269; Wylie (note 46), 8; Katz (note 55), 61 et seq; Fennell (note 55), 1048; Conway \& Stannard (note 55), 77 et seq and 81 et seq; Merrill (note 42), 1134; Stake (note 43), 2434; and Peñalver \& Katyal (note 59), 1145 and 1149. 
grounds supporting the bad faith user's claim to the land. This inquiry is conducted in section 5 .

Current Dutch law reflects the owner's obligation to monitor the use of the land. The possession of the user implies that the owner does not enforce his/her ownership. All that is needed to prevent the user from acquiring the ownership is to send a written notice followed by a legal action. ${ }^{70}$ In light of the Supreme Court's judgment of 24 February 2017, Dutch law also seems to reflect the opinion that the owner's negligence does not necessarily justify bad faith acquisitions by prescription. Dutch law gives the former owner the opportunity of reclaiming his land back from a bad faith acquirer.

\subsection{The Failure to Make Productive Use}

The second type of the negligence justification is that acquisitions by prescription punish the owner for not using the land and encourage the effective use of land. It is submitted that this justification is generally not adequate to justify acquisitions by prescription and at most only partially reflected by current Dutch law. The decisive reservation against this justification is that it indiscriminately favours use over non-use. However, non-use may be socially more valuable than use. ${ }^{71}$ For instance, environmental protection dictates that not all land should be developed, in particular important habitats. ${ }^{72}$ Another concern is that the prospect of an acquisition by prescription would not encourage effective use during the prescription period because the user, unless s/he is in good faith, is unlikely to make major investments because s/he may be evicted..$^{73}$ In sum, encouraging effective land use would not only be a questionable aim, but acquisitions by prescription would be an inadequate means to achieve the aim.

Current Dutch law does not incorporate this justification. As has already been concluded, it does not punish the owner for not using the land, but for not monitoring and controlling its use. Acquisitions by prescription are also an ineffective means to encourage an effective use of the land by the user under Dutch law. In addition to the incentive not to invest during the prescription period, the requirement of 'possession' mainly requires putting up a kind of boundary, but not an effective use of the land.

70 Art. 3:316 and 3:317(2) BW.

71 Fennell (note 55), 1077 et seq; Stake (note 43), 2435 et seq; and Merrill (note 42), 1130.

72 Sprankling (note 41), 840 et seq, 854 et seq, and 863; Fennell (note 55), 1077 et seq; and Merrill (note 42), 1130.

73 Stake (note 43), 2446. 


\section{The User's Moral Claim to the Land as a Justification of Acquisitions by Prescriptions}

The search for reasons why the user should become owner must, as has been concluded above, go beyond the user's reliance upon the owner not bringing an action against them and their interest in legal certainty. ${ }^{74}$ This search leads us to Locke's labour theory, personality theories, and utilitarian considerations. The discussion of such theories, however, also entails weighing the merits of the user's case against the owner's recognised interest in the land. While some scholars wholeheartedly embrace or, at least, acknowledge the necessity of this exercise, ${ }^{75}$ others reject the idea of balancing relative merits. ${ }^{76}$ As there is, however, no overarching public interest, such as legal certainty, that is supposed to trump the interest of the owner in any case, an evaluation of the merits of the user's case and balancing it against the owner's interest are sorely needed.

The following sub-sections discuss the reasons for reallocating the land to the user and their relationship to the owner's interest. Each sub-section then inquires whether Dutch law has already incorporated the alternative justification.

\subsection{Good Use of the Land}

If the user makes good use of the land, s/he will arguably over time acquire a moral claim to the land that may justify a reallocation of ownership from the negligent owner to the user. Cobb \& Fox and Marais have put forward this argument on the basis of Locke's Labour Theory. ${ }^{77}$ Under Locke's theory, the person who mixes his/ her labour with unclaimed land acquires ownership to the land. ${ }^{78}$ This rule, how-

74 Cf. Smeehuijzen (note 42), 20.

75 See, for instance, Brown (note 54), 598; Peñalver \& Katyal (note 59), 1045; and Fennell (note 55), 1064.

76 Wylie (note 46), 8 and 12 et seq; and H.W. Ballantine, 'Title by Adverse Possession' [1918] Harvard Law Review 135.

77 Cobb \& Fox (note 57), 250; and Marais (note 2), 188. See for similar arguments: Peñalver \& Katyal (note 59), 1170; A.-F. Debruche, G. Tepedino \& P. Renteria, 'Protecting Possession, a Question of Values? A Comparative Inquiry into the Moralization of Possession in Brazil and Canada', [2014] Revue générale de droit 391, 432 et seq; and Brown (note 54), 598. Cf. Radin (note 46), 750.

78 J. Locke, Two Treatises of Government, originally published in 1690, in: P. Laslet (ed) (New American Library 1963), §§ 26-28, 34 and 44. 
ever, does not apply to land that already has an owner. ${ }^{79}$ It thus seems that acquisitions by prescription could not be justified on the basis of this theory. Scholars have proposed two ways to overcome this obstacle. Marais has pointed out that Locke assumed an abundance of available land and considered that owners should only acquire as much land as they actually needed and not neglect their land. ${ }^{80}$ Marais argued that there is a scarcity of land nowadays and that owners do neglect their land. For this reason, Locke's theory would arguably permit that effective users of the land acquire it by prescription. ${ }^{81}$ Cobb \& Fox have linked the owner's neglect to the user's good use to argue that the labour theory provides a justification for acquisitions by prescription. The owner's neglect of the land constitutes in their view quasi-abandonment of the land. The land could thus be viewed as unclaimed again, and the user could claim ownership of the land on the basis of his/her good use. ${ }^{82}$ Marais also subscribes to this argument. ${ }^{83}$

It is submitted that the combination of the owner's neglect and the user's good use of the land (over a long period of time) should in most cases be sufficient to justify a reallocation of the ownership to the user. This justification provides a valid reason for why the user should become owner and, at the same time, relies upon the owner's failure to monitor and control the use of the land. The burden imposed upon the owner, which is to monitor the use of the land and interfere where necessary, is not too cumbersome, not even for public bodies owning land; ${ }^{84}$ in particular, this justification does not introduce an obligation for the owner to make good use of the land and allows them to leave the land unused so as to put to a desirable use in the future. ${ }^{85}$

What is problematic about this justification, however, is that it creates an incentive to make use of any kind of land, regardless of whether the land should be left undeveloped. ${ }^{86}$ In particular to protect the environment better, one should consider excluding certain sensitive areas from the scope of applicability of legislation on acquisitions by prescription. ${ }^{87}$

Dutch law and legal practice do not reflect this newly formed justification. Users who make good use of the land may acquire the land by prescription, but

79 Radin (note 46), 750; Cobb \& Fox (note 57), 249; and Epstein (note 41), 674.

80 Marais (note 2), 184 et seq, referring to Locke (note 78), §§ 27, 33 and 37 et seq.

81 Marais (note 2), 184 et seq.

82 Cobb \& Fox (note 57), 250.

83 Marais (note 2), 188.

84 Raising this question: J.E. Jansen, 'Schadevergoeding uit onrechtmatige daad na verkrijging door artikel 3:105 BW' [2018] THEMIS 2018, 3.

85 Cf. Cobb \& Fox (note 57), 250; Brown (note 54), 598; and Marais (note 2), 183 et seq.

86 See footnote 72 .

87 Sprankling (note 41), 862-884. 
do not necessarily meet the requirements for an acquisition. A user who makes good use of the land, but does not fence in the land will not be possessor of the land and fail to meet the requirements of either Art. 3:99 or Art. 3:105 BW. Also, good use is not a requirement for acquisitions by prescription. Art. 3:105 BW does not require long-term use of the land; it is rather sufficient to be the possessor at the moment the owner's rei vindicatio prescribes. It is, moreover, sufficient to close off the land to become possessor under Dutch law; good use is not required. To adopt this justification, Dutch law would thus have to adjust the requirements for an acquisition by prescription.

\subsection{The Land's Contribution to the User's Human Development}

Personality theories lay bare the connection between property rights in material resources and a person's development. They are based upon the Hegelian personality theory, which is aimed at the promotion of personal autonomy and state that personal autonomy requires a material foundation in the form of secure property ${ }^{88}$ Personality theories thereby indicate the importance of the illegally used land to the user's life and may provide a justification for a reallocation of land ownership to the user. In this sub-section I discuss the implications of Radin's personhood theory and Alexander's human flourishing theory for the justification for acquisitions by prescription.

Radin's personhood theory says that a human being needs material resources at their disposal to develop and realise their potential. ${ }^{89}$ Things become bound up with who we are as a person to a varying extent. Radin distinguishes between personal property and fungible property on opposite extremes of a continuum..$^{90}$ The qualification of a thing as personal or fungible property depends upon how much pain the person would suffer if the object were taken away. ${ }^{91}$ Personal property, for example, includes a home and a wedding ring. In Radin's view, personal property has a stronger moral claim to protection by the legal system than fungible property..$^{92}$

88 G.S. Alexander \& E.M. Peñalver, Introduction to Property Theory (Cambridge University Press 2012), 172 et seq. See, for example, also O.W. Holmes, 'The Path of the Law' [1897] Harvard Law Review 457, 477.

89 M.J. Radin, Reinterpreting Property (University of Chicago Press 1993), 153 et seq; and M.J. Radin, 'Property and Personhood' [1982] Stanford Law Review 957.

90 Radin (note 89), 969.

91 Radin (note 89), 959 and 1003.

92 Radin (note 89), 986. 
The importance of the land to the user's personhood, in the form of a home or otherwise, may justify an acquisition by prescription..$^{93}$ There is, however, some debate about the conditions under which this reallocation should take place. Radin herself states that personhood-related considerations would mainly justify a reallocation to good faith users. She raises the question of how a bad faith user could get bound up with the land. ${ }^{94}$ It is submitted that by using the land and, for instance, living on the land with one's family, a person gets automatically bound up with the land and that the issue of whether the person has a recognised right to use the land fades into the background. So, even to a bad faith user, the land may be personal property. The other issue is to what extent the owner's attachment to the land must have diminished so that the user's attachment to the land sufficiently outweighs it to justify a reallocation of ownership. Several scholars have indicated that the owner would have to have no personal attachment to the land whatsoever. ${ }^{95}$ It is submitted that in cases other than boundary disputes, the fact that an owner fails to monitor and control the use of his land for a long period of time should be regarded as a form of quasi-abandonment and sufficient evidence for a lack of personal attachment. ${ }^{96}$

The land's importance to the user's personhood and the lack of attachment to the land on the part of the owner nicely combine the justification based upon the land's contribution to the user's human development and the 'punish the neglectful owner'-rationale. One problem with this justification is that it is difficult to imagine that it applies to acquisitions by legal persons. ${ }^{97}$ However, the legal person could have an attachment to the land through its members or shareholders. Supposing that the members of a football club occupy green space, turn it into a pitch, and play on it for decades, why should there not be a justification for the football club to acquire the land on the basis of the members' attachment to the land?

That said, Dutch law would have to be substantially changed to incorporate this justification. Users with great personal attachment may acquire by prescription, but they do not necessarily acquire it. Specifically, the Dutch requirement of possession does not distinguish between owners or users on the basis of how attached the user or owner is to the land respectively. Instead, Dutch case law

93 Merrill (note 42), 1127 and 1131; Marais (note 2), 195; Radin (note 46), 748 et seq; and Cobb \& Fox (note 57), 250 et seq.

94 Radin (note 46), 749. See the even stricter approach of R.A. Posner, Economic Analysis of Law $\left(6^{\text {th }}\right.$ edn, Aspen Publishers 2003), 78.

95 Cobb \& Fox (note 57), 252; and Stake (note 43), 2456. Cf. Radin (note 46), 749.

96 Marais (note 2), 195 et seq. Differing: Stake (note 43), 2456.

97 Radin (note 46), 749. 
differentiates on the basis of the function of the land and whether the land is publicly or privately owned. Also, personal attachment is no necessary requirement for an acquisition. The user does not even need to use the land to acquire by prescription; fencing in the land is sufficient.

A similar argument could be made on the basis of Alexander's human flourishing theory. Human flourishing is an objective standard by which the ability of a person to participate in human activities is measured. The more people are able to participate in human activities, the more a society guarantees human flourishing. ${ }^{98}$ Property may contribute to human flourishing because property fosters personal autonomy, security, and wealth. ${ }^{99}$ Marais has argued that a reallocation to the user and secure ownership would foster the user's capabilities to live a well-lived life. As the owner has a societal obligation to look after the land, but failed to honour this obligation, it is then justified in Marais' opinion to deprive the owner of the land. ${ }^{100}$ This approach is persuasive. This justification, again, nicely combines the issue of why the user should become owner with the question of why the owner should lose the land. The long-term use of the land for human flourishing-enhancing purposes, as a home for example, explain why the land is important to the user; the failure to monitor and control the use of the land suggests that the land no longer bears any importance to the owner's human flourishing.

Dutch law, however, would have to be substantially changed to incorporate this justification. The reasons are the same mentioned with respect to the personhood theory. In short, the requirements for acquisition by prescription do not distinguish between users and owners on the basis of whether the land contributes to their human flourishing.

\subsection{The User's Net Contribution to Aggregated Utility}

Utilitarian theories seek to maximise the aggregated utility within society. ${ }^{101}$ In the literature, various authors have pointed out that land should be allocated to the person who accords the highest subjective value to it. ${ }^{102}$ As time proceeds, the

98 G.S. Alexander, 'The Public Use Requirement and the Character of Consequentialist Reasoning' in B. Hoops et al (eds), Rethinking Expropriation Law II, Context, Criteria, and Consequences of Expropriation (Boom Eleven 2015) 113-135, 114 et seq.

99 Alexander (note 98), 124 et seq.

100 Marais (note 2), 201 et seq.

101 J.M. Kelly, A Short History of Western Legal Theory (Clarendon Press 1992), 315.

102 See, for instance, Cobb \& Fox (note 57), 252; Fennell (note 55), 1064; and Peñalver \& Katyal (note 59), 1045. 
value that the user attaches to the land increases, while the owner accords less and less value to the land. There might indeed be a point in time when the aggregated utility within society would be higher if the ownership were allocated to the user. This may constitute a justification of acquisitions by prescription.

Law and economics theory, aimed at maximising the economic efficiency of the use of resources, provides a useful instrument to measure overall utility. Several scholars have conducted economic analyses of acquisitions by prescription. ${ }^{103}$ This contribution cannot examine all their analyses in depth. Instead, this contribution briefly discusses a recent (theoretical) analysis conducted by Marais. ${ }^{104}$

Marais measured the costs incurred by the owner, the costs incurred by the user, the costs incurred by third parties, and litigations costs caused by legislation on acquisitions by prescription. These costs add to the loss caused to the owner by the acquisition by prescription itself. At a societal level, however, the loss sustained by the owner is (assumed to be) offset by the higher value that the user attaches to the land. Marais analysed how these costs relate to the length of the prescription period. He argues that the owner's costs, caused by uncertainty, monitoring of the land, and demoralisation linked to the loss of property to the user, decrease as the prescription period becomes longer. ${ }^{105}$ This is plausible because the longer the prescription period is, the less the owner will worry about their property. Also, if the owner does not monitor their property for a longer period of time and then loses the land, s/he will be more likely to suffer less pain (or 'demoralisation'). According to Marais, the user incurs costs for uncertainty, obtaining evidence for a succeeding prescription claim, and demoralisation (due to eviction). ${ }^{106}$ One should, possibly, add lost investments that may occur if the owner successfully reclaims the land. Marais argues that these costs are highest if the prescription period is very short, then gradually decrease, and then increase again as the prescription period becomes longer than 10 years. ${ }^{107}$ This conclusion seems plausible in that uncertainty is highest at the beginning (that is, for bad

103 M. Baker et al, 'Property Rights by Squatting: Land Ownership Risk and Adverse Possession Statutes' [2001] Land Economics 360-370; Miceli \& Sirmans (note 54); J.M. Netter, P.L. Hersch \& W.D. Manson, 'An Economic Analysis of Adverse Possession Statutes' [1986] International Review of Law and Economics 217-227; and R.C. Ellickson, 'Adverse Possession and Perpetuities Law: Two Dents in the Libertarian Model of Property Rights' [1986] Washington University Law Quarterly 723-737.

104 Marais (note 2), 218 et seq.

105 Marais (note 2), 218 et seq.

106 Marais (note 2), 222 et seq.

107 Marais (note 2), 222 et seq. 
faith acquirers) and in that the demoralisation costs and the value of investments increase as the user lives longer on the land.

Third party acquirers may incur (prescription-related) costs for the title search (conducted by the civil law notary in the Netherlands), an inspection of the site, and uncertainty about the acquisition. Marais points out that on the one hand, (registered or unregistered) acquisitions by prescription may correct flawed information in the register, which enhances certainty, and on the other hand, they may introduce wrong information because the acquirer by prescription does not need to register the acquisition. ${ }^{108}$ In the Dutch context, inspections will only be useful and acquisitions by prescription will only correct (or, rather, complement) the land register if there is a boundary dispute and the boundary cannot be ascertained from the available information. In all other cases, acquisitions by prescription that remain unregistered will make site inspections necessary that would otherwise not have been required, and thereby increase transaction costs. A regime that does not allow for acquisitions for prescription in those cases would thus bring down transaction costs. Marais argues that the costs incurred by the third party acquirer are highest if the prescription period is very short, then decrease, and later slowly, but steadily increase as the prescription period becomes longer. ${ }^{109}$ This seems plausible because if the prescription period were shorter, third parties who try to acquire from the owner would feel very uncertain about their acquisitions and undertake (possibly unnecessary) additional inspections. If the prescription period were longer, third parties would, at least in boundary disputes, incur more costs for title search and inspections because the information becomes less reliable.

Litigation costs caused by legislation on acquisitions by prescription are composed of the number of litigated cases and the costs of flawed judicial decisions. ${ }^{110}$ Marais argues that the shorter the prescription period is, the more litigated case there will be and the higher the litigation costs will be. If the prescription period is higher, however, there will be more flawed decision due to information of worse quality. ${ }^{111}$ In the Dutch context, the latter is only true where the land register does not provide reliable information, i.e. in boundary disputes or where an inheritance has remained unregistered. ${ }^{112}$

Based upon this analysis, it is submitted that at the moment the (demoralisation and investment) costs linked to evicting the user are higher than the

\footnotetext{
108 Marais (note 2), 225.

109 Marais (note 2), 226 et seq.

110 Ellickson (note 103), 731.

111 Marais (note 2), 229 et seq.

112 Kolkman et al (note 38).
} 
combined additional costs caused to the owner, third party acquirers, and the general public, there is an economic justification for an acquisition by prescription. It depends upon a country's system of land registration, judicial system, and culture at which point this line is crossed.

Dutch law currently does not incorporate this justification for essentially the same reason why it does not reflect the other alternative justifications for acquisitions by prescription. High demoralisation costs on the part of the user are neither required nor sufficient to acquire the land by prescription. A user could develop a strong link to the land by using it, but would only acquire it if he had fenced it in. By contrast, a user who does not have any strong link with the land, but has fenced in the land may become owner.

\section{The Promotion of Equality as a Justification of Acquisitions by Prescriptions}

Economic inequality has an adverse impact upon democratic participation, education, public health, security, and social mobility. ${ }^{113}$ In times of increasing inequality of income and wealth and weakening welfare states in the Global North, it is tempting to think of acquisitions by prescription as a means to redistribute wealth from the haves to the have-nots and, thereby, reduce economic inequality. ${ }^{114}$ Moreover, it would not be without historical precedence: the generous application of adverse possession to settlers in the United States in the $19^{\text {th }}$ century, for instance, constituted a redistribution of land ownership from large holders of land to those without security of tenure. Although the courts relied upon the owner's negligence to justify the reallocation, the political motivation was to spur economic development by providing incoming settlers with access to land. ${ }^{115}$

A closer analysis, however, shows that acquisitions by prescription are not an adequate means to alleviate economic inequality in the Global North. If the land is used for agricultural purposes, the previously poor and landless user could only use the land to undertake farming for subsistence. If the user is able to acquire the equipment for subsistence farming at all, s/he will in any case lack the means to compete with the big agricultural companies of the $21^{\text {st }}$ century and

113 R.G. Wilkinson \& K. Pickett, The Spirit Level (Allen Lane 2009).

114 Peñalver \& Katyal (note 59).

115 Sprankling (note 41), 844; Peñalver \& Katyal (note 59), 1105 et seq. 
generate significant wealth. An acquisition by prescription would thus only lead to a minimal standard of living in a rural environment, which is likely not to appeal to most people. Moreover, most of today's welfare states in the Global North still guarantee this standard of living. In the Global South, by contrast, acquisitions by prescription may redistribute much needed land for subsistence farming to the landless.

If the user uses the land for residential purposes, acquisitions by prescription may provide security of tenure to the users and literally create a home base for generating income and creating wealth. In the Global South and countries in the Global North with a shortage and insufficient public provision of affordable housing and vacant housing space, acquisitions by prescription may thus alleviate symptoms of economic inequality. The Kraken (squatting) movement in the Netherlands of the 1960s, 70s, and 80s provides an example. ${ }^{116}$

However, even where acquisitions by prescription could potentially alleviate symptoms of economic inequality in the Global North, it is unlikely to do that and it also remains inadequate to combat economic inequality. The first reason is that the long prescription period for bad faith acquirers, 20 years in the Netherlands, creates an incentive for the users not to invest in the land and a prolonged period of insecure tenure. ${ }^{117}$ This reduces the potential emotional security provided by a home. The second reason is that occupying other people's land is likely to make the users outlaws or reinforce this status within the community, which would hamper the economic and social development of the users and their families. This may only be different where it becomes "normal" or even "trendy" to occupy other people's land because a significant part of the population or children of members of the middle class struggle to find adequate housing. Again, the Kraken movement in the Netherlands is an illustrative example.

The third and possibly most important reason is, as has already been pointed out, that land alone cannot help the poor in the Global North generate significant income. While the rich use expensive real estate to store and expand their already existing wealth, the poor do not have this option. The complex high-tech economies of the Global North pose educational entry barriers, such as administrative, legal, or technological expertise. Even with a home, the poor cannot generate a decent income without access to education. Only a good public education system can provide the poor with the knowledge required to enter the sectors promising a high and stable income, which may then reduce economic inequality. Compared

116 Cf. Hoops (note 64), 47 et seq.

117 Brown (note 54), 598. 
to acquisitions by prescription, a capable welfare state would thus be a better instrument.

Neither Dutch law nor practice shows any sign of acquisitions by prescription being an instrument for redistribution. The financial situation of the user is irrelevant to the application of Art. 3:99 and 3:105 BW. Only the user's physical control of the land and the question of whether or not $\mathrm{s} /$ he acts in good faith are taken into account. Art. 3:99 BW, moreover, only benefits users who meant to lawfully acquire the land from its owner, ${ }^{118}$ which will never be the case with landless people without sufficient means to acquire land. Art. 3:105 BW may facilitate redistribution. However, the Supreme Court recently ruled that the former owner could still reclaim the land up to 20 years after the acquisition by prescription, ${ }^{119}$ prolonging the period of uncertainty. This limits the potential for redistribution. In Dutch legal practice, most illegal land users add somebody else's land to the land that they already own. ${ }^{20}$ Squatting is the exception and, if it occurs, today's squatters are mostly outlaws who cannot count on the public's support. ${ }^{121}$

\section{Conclusion}

Legal institutions tend to weather the ravages of time. They persist even though the original justification of their rules has been long forgotten or no longer holds any water. Legal certainty as a justification for acquisitions by prescription in the Netherlands only partially falls into this category. If a registered transfer was not effective, the registered owner (and his/her successors in title) is dead or lost without trace, or the boundaries cannot be ascertained from the public records and the land register, legal certainty will still be at stake and an acquisition by prescription will restore legal certainty. As boundary disputes occur very frequently in the Netherlands, legal certainty still has a big role to play. However, in other cases, in particular where a person occupies land knowing that it is somebody else's, legal certainty fails to explain why the user should be elevated to owner.

The argument that the neglectful owner should be punished for not monitoring and controlling the use of the land is persuasive in most cases. The public interest in this punishment is to encourage the owner to avoid wasteful conflicts

118 See sub-section 2.1 above. $C f$. Cobb \& Fox (note 57), 253.

119 Hoge Raad (HR), 24 February 2017, ECLI:NL:HR:2017:309.

120 Hoops (note 10).

121 See, for instance, Rechtbank Amsterdam, 18 April 2007, ECLI:NL:RBAMS:2007:BA5589. 
over such a valuable resource as land. Dutch law also reflects this justification because the owner merely needs to claim back the possession of the land to end the prescription period running.

However, this justification may explain why the owner should lose the ownership; it does not justify why the user should acquire the ownership. This is primarily problematic where user knew that he was occupying somebody else's land. The value judgement expressed in judgments of the Dutch Supreme Court and the literature that bad faith users should not be rewarded and that there should be no incentive to occupy (or 'steal') land, is too emphatically advocated in the Netherlands to let the 'punish the neglectful owner'-rationale justify an acquisition by bad faith users.

A combination of the 'punish the neglectful owner'-rationale and a valid reason why the user should become owner, however, could even justify acquisitions by bad faith users. Good use of the land, the land's importance to the user's personal development, or the utilitarian consideration that evicting the user would do more harm to aggregated utility than making the user owner, could very well justify a reallocation of the land. The promotion of equality, by contrast, would not constitute an adequate justification in the Global North. Access to agricultural land will not result in poor people generating significant income or wealth. Access to a home forms a basis for improving their livelihoods. However, the long prescription period is a long period of uncertainty for squatters. Squatting and an acquisition by prescription also make the users outlaws in most societies in the Global North. Lastly, an acquisition by prescription by no means gives them access to the tools needed for generating income in the economy of the $21^{\text {st }}$ century.

Dutch law would yet have to incorporate the novel justifications for acquisitions by prescription presented in this contribution. This is a difficult undertaking because it depends upon the circumstances of each case whether the user, for example, has a sufficient link with the land. Reconciling this need for differentiation with the need for legal certainty in property law will automatically lead to imperfections, leaving the proponents of the discussed theories unsatisfied. ${ }^{122} \mathrm{~A}$ step in the right direction, however, would be to differentiate between different uses of the land and link them to diverging prescription periods. If the user uses the land for residential purpose, for instance, the law could assume that there is an important emotional link between the user and the land and should shorten the prescription period accordingly. Agricultural or commercially used land, by contrast, could be subject to relatively longer prescription period.

122 Cf. Merrill (note 42), 1137 et seq. 